\title{
EVALUATION OF GROUNDWATER QUALITY IN BHOGAVATI RIVER BASIN, KOLHAPUR DISTRICT, MAHARASHTRA, INDIA
}

\author{
P. A. Pisal ${ }^{1}$, A. S. Yadav ${ }^{2}$ \\ ${ }^{I}$ Assistant Professor, Department of Civil Engineering, ADCET, Ashta, India \\ ${ }^{2}$ Assistant Professor, Department of Civil Engineering, Dr.JJMCOE, Jaysingpur, India
}

\begin{abstract}
The assessment of groundwater quality of bore wells of the Bhogavati river basin (latitude 16 $16^{\prime} 45^{\prime \prime} \mathrm{N}$ to $16^{\circ} 44^{\prime} 30^{\prime \prime} \mathrm{N}$ and longitude 73 $50^{\prime} 15^{\prime}$ E to 74 11'50”E) in Kolhapur District, Maharashtra, India was carried out and 40 dug well water samples were collected. The physico-chemical analyses of these water samples reveal that $90 \%$ and $92.5 \%$ groundwater samples represent $\mathrm{Ca}+\mathrm{Mg}$ (alkaline earth) hydrochemical facies in pre and post-monsoon seasons respectively, whereas, 10\% of groundwater samples in pre-monsoon season and $7.5 \%$ of groundwater samples in post-monsoon season represent Ca+Mg $>\mathrm{Na}+\mathrm{K}(\mathrm{alkaline}$ earths exceed alkalies) hydrochemical facies. Similarly, $82.5 \%$ groundwater samples of pre-monsoon season and $77.5 \%$ groundwater samples of post-monsoon season represent $\mathrm{Cl}+\mathrm{SO}_{4}>\mathrm{HCO}_{3}+\mathrm{CO}_{3}$ (strong acid exceeds weak acid) hydrochemical facies, while $17.5 \%$ groundwater samples of pre-monsoon season and $22.5 \%$ groundwater samples of post-monsoon season belong to $\mathrm{HCO}_{3}+\mathrm{CO}_{3}>\mathrm{Cl}+\mathrm{SO}_{4}$ (weak acid exceeds strong acid) hydrochemical facies. On the basis of Gibbs diagram the chemistry of groundwater belongs to precipitation dominance in pre-monsoon season and rock dominance in post-monsoon season.
\end{abstract}

Keywords: Bhogavati River Basin, Groundwater Quality, Hydrochemical Facies, Parameters.

\section{INTRODUCTION}

Groundwater is the almost source of water in drought prone monsoon semiarid or arid regions, for drinking domestic, industrial and irrigation purpose. Groundwater never found in pure state. As water come from the atmosphere $\mathrm{CO}_{2}$ and failing on the ground carbonic acid as a powerful corrosive agent. It react with geomaterial and acquires a certain characteristics before entering in the ground its chemical properties may changes from its place of entry to the point of exit. Natural quality of water depends upon its interaction with rocks and various geochemical reaction.

Due to excessive use of pesticides, fertilizers for agriculture, industrial waste water, domestic waste water etc. pose serious problem of water pollution. [1] Therefore, water quality monitoring of various sources is very essential to know the status so as to suggest safety measures. Groundwater is mostly chemically non-polluted when drawn from greater depth. Human beings have made aquifer as their prime requisite due to unavailability of reliable source of water as that of the groundwater. So during past several decades, groundwater quality has emerged as one of the most important and confronting environmental issue [2]. Water quality analysis is one of the most important aspects in groundwater studies. The hydrochemical study reveals quality of water that is suitable for drinking, agriculture and industrial purposes. According to National Water Policy, (2012) both surface and groundwater should be regularly monitored and program should be undertaken for the improvement of water quality. The main objective of this paper is to carry out a hydrochemical appraisal of groundwater in Bhogavati river basin of Kolhapur district, Maharashtra, India. This includes the determination of the general water quality, major ionic constituents, hydrochemical facies, geochemical processes responsible for changes, and variations in the groundwater quality.

\section{STUDY AREA}

The Bhogavati river basin lies between latitude $16^{0} 19^{\prime} 45^{\prime}$ ' $\mathrm{N}$ to $16^{0} 44^{\prime} 30^{\prime \prime} \mathrm{N}$ and longitude $73^{0} 50$ ' $15^{\prime}$ ' $\mathrm{E}$ to $74^{0} 11^{\prime} 50^{\prime}$ ' $\mathrm{E}$ in Survey of India Toposheet numbers $47 \mathrm{H} / 15,47 \mathrm{~L} / 2$ and 47 $\mathrm{L} / 3$. The area of Bhogavati river basin is about $440 \mathrm{~km}^{2}$ (Figure 1). The Bhogavati river is one of the major tributary of the Panchaganga river and Panchaganga river is a tributary of river Krishna. The study area is covered by Deccan volcanic basalt of Upper Cretaceous to Lower Eocene age. The climate of the area comes across as an amusing blend of the coastal and inland climate of Maharashtra. The temperature of the area ranges between $10^{\circ} \mathrm{C}$ and $40^{\circ} \mathrm{C}$. The average annual rainfall of the area is about $4800 \mathrm{~mm}$. 


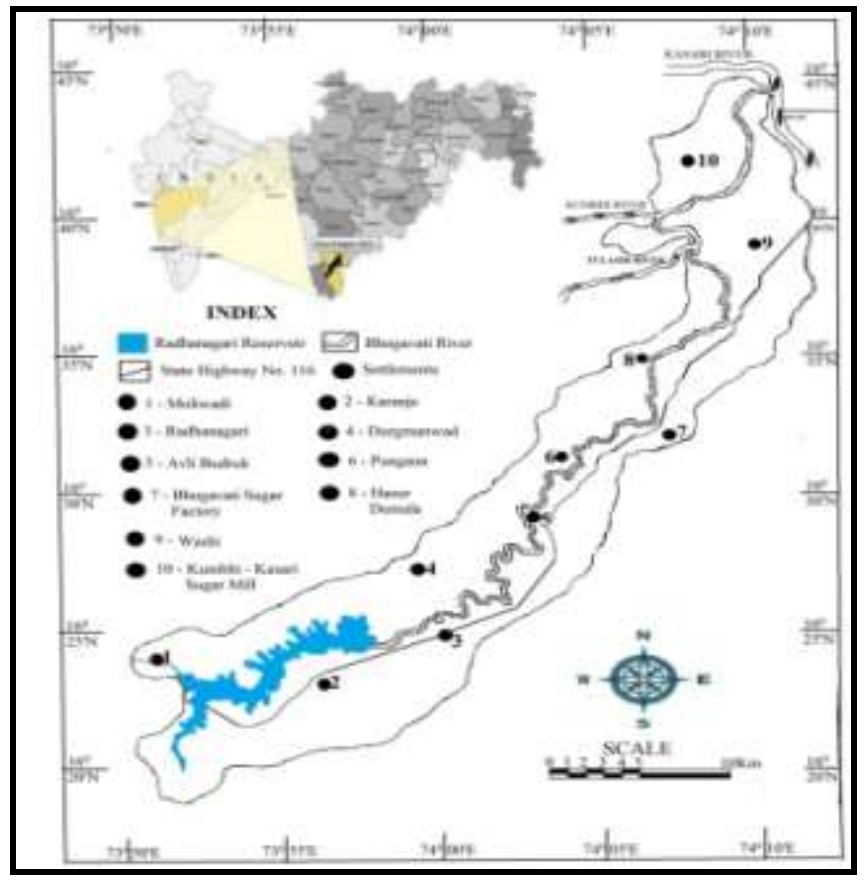

Fig 1: Location Map of the study area.

\section{METHODOLOGY}

Groundwater samples were collected from 40 bore wells during pre and post- monsoon seasons of the year 2013. (Figure 2). The polythene bottles were used for sample collection. The samples were analyzed in the laboratory for various physicochemical parameters by standard procedures [3], [4] and [5] (Table 1 and 2). The analysis of total alkalinity (TA), total hardness (TH), Calcium $\left(\mathrm{Ca}^{2+}\right)$, Sodium $\left(\mathrm{Na}^{+}\right)$, Potassium $\left(\mathrm{K}^{+}\right)$, Bicarbonate $\left(\mathrm{HCO}_{3}{ }^{-}\right)$and Chloride $\left(\mathrm{Cl}^{-}\right)$were determined by titration. The $\mathrm{pH}, \mathrm{EC}$ and TDS were calculated by using $\mathrm{pH}$ meter, EC meter and TDS meter respectively.

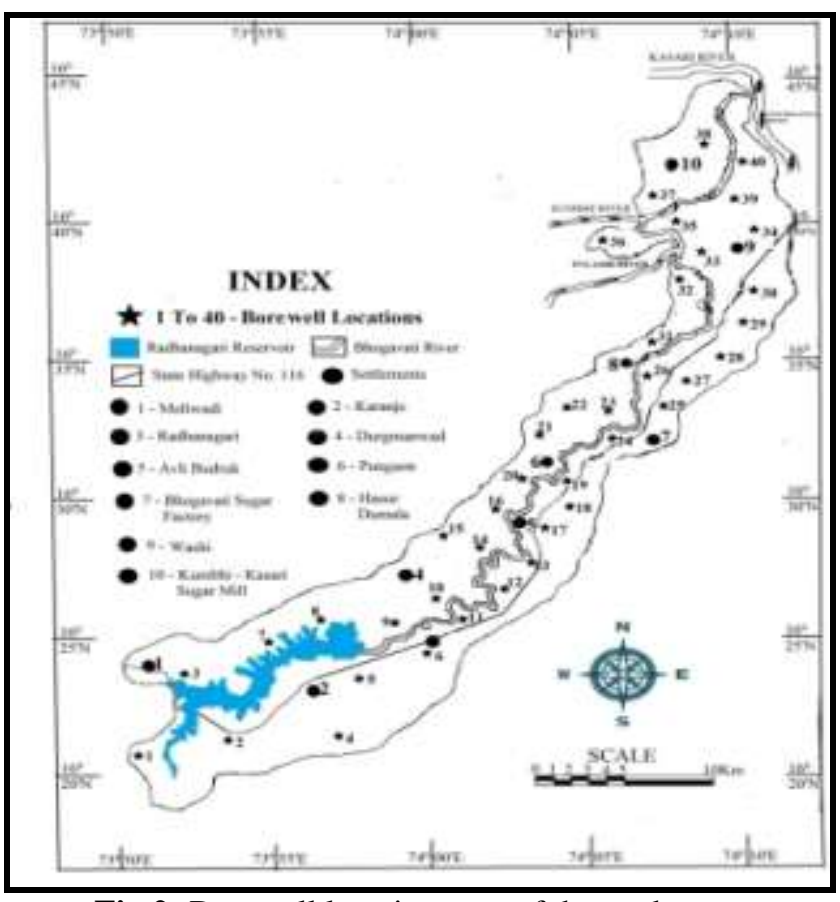

Fig 2: Dug well location map of the study area

\section{RESULT AND DISCUSSION}

The concentrations of Sodium $\left(\mathrm{Na}^{+}\right)$and potassium $\left(\mathrm{K}^{+}\right)$in the groundwater were measured by using flame photometer. The spectrophotometer was used for the determination of $\mathrm{SO}_{4}$.

\subsection{Hydrogen Ion Concentration $(\mathrm{pH})$}

The $\mathrm{pH}$ of water is measured in the field at the time of collection of samples. The combination of $\mathrm{CO}_{2}$ with water forms carbonic acid, which affects the $\mathrm{pH}$ of the water. The $\mathrm{pH}$ of groundwater samples is varies from 6.0 to 9.7 and 5.6 to 9.9 in pre monsoon and post- monsoon seasons respectively (Table 1 and 2), which indicates that some groundwater samples in both the seasons are slightly alkaline in nature. (Table 3 ).

\subsection{Electrical Conductivity (EC)}

Electrical Conductivity is the measure of water capacity to convey electric current. The EC of groundwater samples is varying from $116.7 \mu \mathrm{mhos} / \mathrm{cm}$ to $2046.5 \mu \mathrm{mhos} / \mathrm{cm}$ and $104.4 \mu \mathrm{mhos} / \mathrm{cm}$ to $1659.8 \mu \mathrm{mhos} / \mathrm{cm}$ in pre-monsoon and post-monsoon seasons respectively (Table 1 and 2), which shows that in both the seasons only 2 groundwater samples exceeds most desirable limit given by WHO International standards (2004) (Table 3).

\subsection{Total Dissolved Solids (TDS)}

TDS is the concentrations of all dissolved minerals in water indicates the general nature of salinity of water. The TDS ranges between $361.9 \mathrm{mg} / \mathrm{l}$ to $2183.6 \mathrm{mg} / \mathrm{l}$ for pre -monsoon season, while it varies from $313.4 \mathrm{mg} / \mathrm{l}$ to $2131.7 \mathrm{mg} / \mathrm{l}$ in post-monsoon season (Table 1 and 2). The TDS values of groundwater samples in the pre-monsoon season are found to be higher as compared to the post -monsoon season. Increase in TDS in pre- monsoon season confirms the interference drawn about higher EC values in this season. It is observed that $2.5 \%$ and $7.5 \%$ groundwater samples in pre and post-monsoon seasons respectively have exceeded maximum allowable limit prescribed by the drinking water standard of WHO (Table 3).

\subsection{Total Hardness (TH)}

The hardness of groundwater samples is in the range of 204 $\mathrm{mg} / \mathrm{l}$ to $1591 \mathrm{mg} /$ lit in pre-monsoon season and $190.7 \mathrm{mg} / \mathrm{l}$ to $1577.9 \mathrm{mg}$ / lit in post-monsoon season (Table 1 and 2). Groundwater with TH $<75$ mg/l, 75-150 mg/l, 150-300 mg/l and $>300 \mathrm{mg} / \mathrm{l}$ are classified as soft water, moderately hard water, hard water and very hard water respectively [6]. The $45 \%$ and $37.2 \%$ groundwater samples are having very hard water in pre and post-monsoon seasons respectively. (Table 3).

\subsection{Calcium (Ca)}

Calcium is determinant of water hardness, because it can be found in water as $\mathrm{Ca}$ ions. In the study area $\mathrm{Ca}$ content in the groundwater samples varies from $81.6 \mathrm{mg} / \mathrm{l}$ to 924.8 
$\mathrm{mg} / \mathrm{l}$ and $72.3 \mathrm{mg} / \mathrm{l}$ to $918.2 \mathrm{mg} / \mathrm{l}$ in pre and post-monsoon seasons respectively (Table 1 and 2). The Ca content in $60 \%$ and $57.5 \%$ groundwater samples were beyond the maximum permissible limit prescribed by WHO and ISI (Table 3).

\subsection{Magnesium (Mg)}

A large number of minerals and rocks contain magnesium and it dissolves in surface and groundwater. It adds up in the environment by use of fertilizer for agricultural practices and from cattle feed [7]. The values of $\mathrm{Mg}$ in groundwater samples range between $54 \mathrm{mg} / \mathrm{l}$ to $698.4 \mathrm{mg} / \mathrm{l}$ and $46.9 \mathrm{mg} / \mathrm{l}$ to $691.8 \mathrm{mg} / \mathrm{l}$ in pre and post- monsoon seasons respectively (Table 1 and 2). The $\mathrm{Mg}$ content in $67.5 \%$ and $82.5 \%$ groundwater samples were crosses the maximum permissible limit in pre-monsoon and post-monsoon seasons respectively prescribed by WHO (Table 3 ).

\subsection{Sodium $(\mathrm{Na})$}

Sodium concentration in groundwater samples of study area is low as compare to $\mathrm{Ca}$ and $\mathrm{Mg}$. Sodium content is varies from $4 \mathrm{mg} / \mathrm{l}$ to $90.5 \mathrm{mg} / \mathrm{l}$ and $2.3 \mathrm{mg} / \mathrm{l}$ to $84.9 \mathrm{mg} / \mathrm{l}$ in pre and post-monsoon seasons respectively (Table 1 and 2). The sodium concentration of groundwater samples both in both seasons were within the safe limit (Table 3).

\subsection{Potassium $(K)$}

The main source of $\mathrm{K}$ in groundwater is weathering of potash silicate minerals and use of potash fertilizers for agriculture practices. The potassium content in groundwater samples ranges in between $0.4 \mathrm{mg} / \mathrm{l}$ to $65 \mathrm{mg} / \mathrm{l}$ in premonsoon season and $0.2 \mathrm{mg} / \mathrm{l}$ to $61 \mathrm{mg} / \mathrm{l}$ in post-monsoon season (Table 1 and 2). In groundwater samples $\mathrm{K}$ concentration does not exceeds the maximum permissible limit prescribed by WHO and ISI (Table 3 ).

\subsection{Total Alkalinity}

Total alkalinity is the total concentration of bases in water expressed as parts per million (ppm) or milligrams per liter $(\mathrm{mg} / \mathrm{l})$ of calcium carbonate $(\mathrm{CaCO} 3)$. These bases are usually bicarbonates (HCO3) and carbonates (CO3), and they act as a buffer system that prevents drastic changes in $\mathrm{pH}$. An alkalinity value varies from $44.5 \mathrm{mg} / \mathrm{l}$ to $284 \mathrm{mg} / \mathrm{l}$ in pre- monsoon season and $23.5 \mathrm{mg} / \mathrm{lit}$ to $274.7 \mathrm{mg} / \mathrm{l}$ in postmonsoon season. (Table 1 and 2). The Total alkalinity of groundwater samples in both seasons were within the safe limit (Table 3).

\subsection{Bicarbonate $\left(\mathrm{HCO}_{3}\right)$}

The values of $\mathrm{HCO}_{3}$ are in the range of $44.5 \mathrm{mg} / \mathrm{l}$ to 284.8 $\mathrm{mg} / \mathrm{l}$ in pre-monsoon season and $9.5 \mathrm{mg} / \mathrm{l}$ to $274.7 \mathrm{mg} / \mathrm{l}$ in post-monsoon season (Table 1 and 2). The bicarbonate values of groundwater samples in both seasons were within the safe limit (Table 3).

\subsection{Sulphate $\left(\mathrm{SO}_{4}\right)$}

Sulphate ions usually occur in natural waters. In the study area $\mathrm{SO}_{4}$ content in the groundwater samples varies from 8.7 $\mathrm{mg} / \mathrm{l}$ to $95.7 \mathrm{mg} / \mathrm{l}$ and $7.2 \mathrm{mg} / \mathrm{l}$ to $93.3 \mathrm{mg} / \mathrm{l}$ in pre and postmonsoon seasons respectively (Table 1 and 2). The concentrations of $\mathrm{SO}_{4}$ are within safe limit (Table 3).

\subsection{Chloride $(\mathrm{Cl})$}

Chloride originates from rocks and soil which gets dissolved in water. Chloride content in the groundwater samples ranges between $27 \mathrm{mg} / \mathrm{l}$ to $167.6 \mathrm{mg} / \mathrm{lit}$ in pre-monsoon season and $16.3 \mathrm{mg} / \mathrm{l}$ to $157.8 \mathrm{mg} / \mathrm{l}$ in post- monsoon season. (Table 1 and 2). This reveals that $\mathrm{Cl}$ content in groundwater samples does not exceed the maximum permissible limit prescribed by WHO and ISI (Table 3).

\subsection{Hydrogeochemical Facies}

The evaluation of hydrochemical parameters of groundwater can be understood by plotting the concentration of major cations and anions in the Piper Trilinear diagram. It helps in recognizing various hydrogeochemical facies in a groundwater environment [8]. The physico-chemical analyses of these water samples reveal that $90 \%$ and $92.5 \%$ groundwater samples represent $\mathrm{Ca}+\mathrm{Mg}$ (alkaline earth) hydrochemical facies in pre and post-monsoon seasons respectively, whereas, $10 \%$ of groundwater samples in premonsoon season and $7.5 \%$ of groundwater samples in postmonsoon season represent $\mathrm{Ca}+\mathrm{Mg}>\mathrm{Na}+\mathrm{K}$ (alkaline earths exceed alkalies) hydrochemical facies. Similarly, $82.5 \%$ groundwater samples of pre-monsoon season and $77.5 \%$ groundwater samples of post-monsoon season represent $\mathrm{Cl}+\mathrm{SO}_{4}>\mathrm{HCO}_{3}+\mathrm{CO}_{3}$ (strong acid exceeds weak acid) hydrochemical facies, while $17.5 \%$ groundwater samples of pre-monsoon season and $22.5 \%$ groundwater samples of post-monsoon season belong to $\mathrm{HCO}_{3}+\mathrm{CO}_{3}>\mathrm{Cl}+\mathrm{SO}_{4}$ (weak acid exceeds strong acid) hydrochemical facies ( Figure 3 and 4).

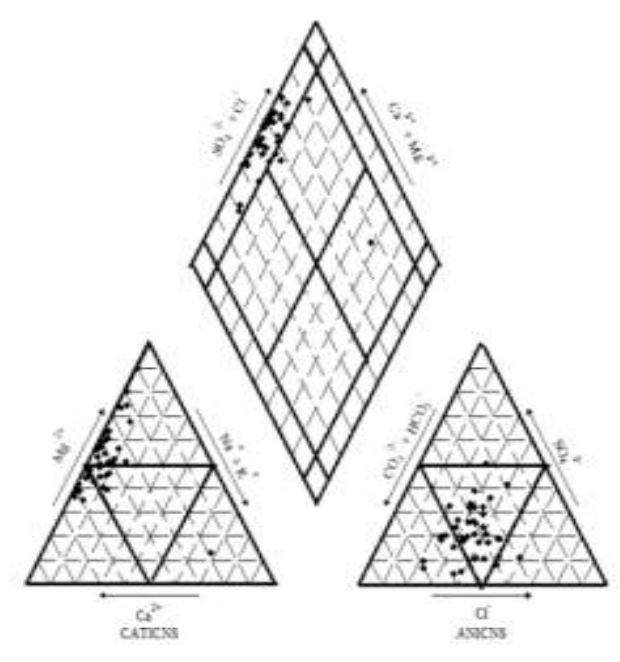

Fig. 3: Piper Trilinear diagram of groundwater quality (pre-monsoon season) 


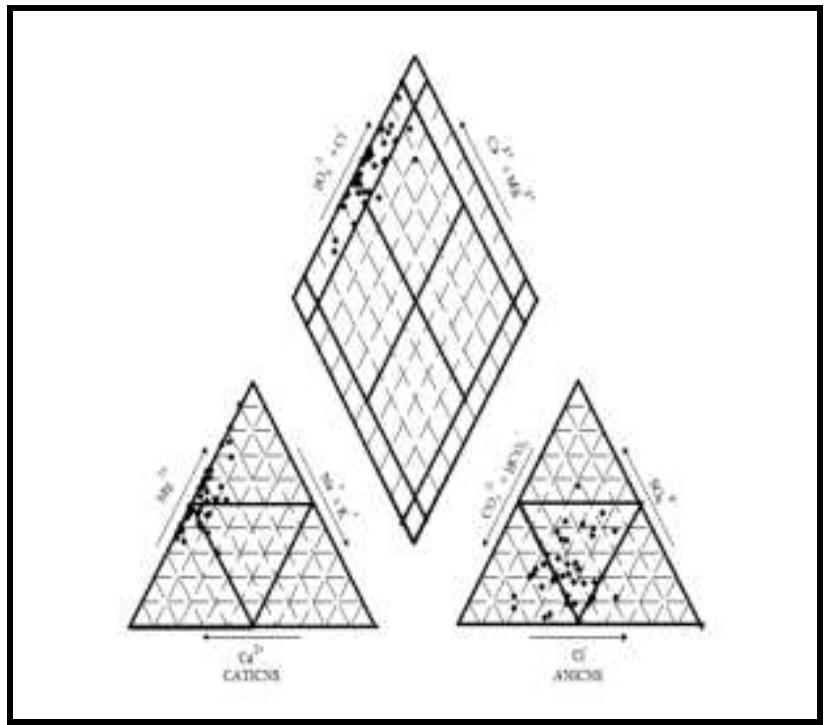

Fig. 4: Piper Trilinear diagram of groundwater quality (post-monsoon season)

\subsection{Gibbs Diagram}

The quality of groundwater is significantly changed by the influence of weathering and anthropogenic inputs. Gibbs's diagrams, representing the ratios of $\mathrm{Na}^{++}:\left(\mathrm{Na}^{++} \mathrm{Ca}^{++}\right)$and $\mathrm{Cl}^{-}:(\mathrm{Cl})+\mathrm{HCO}_{3}$ as a function of TDS, are widely employed to assess the functional sources of dissolved chemical constituents, such as precipitation-dominance, rockdominance and evaporation-dominance [9]. Three distinct fields such as precipitation dominance, evaporation dominance and rock- water interaction dominance areas are shown in the Gibbs diagram (Figure 5 and 6). The chemistry of groundwater samples of study area belongs to precipitation dominance in pre-monsoon season and rock dominance in post-monsoon season.

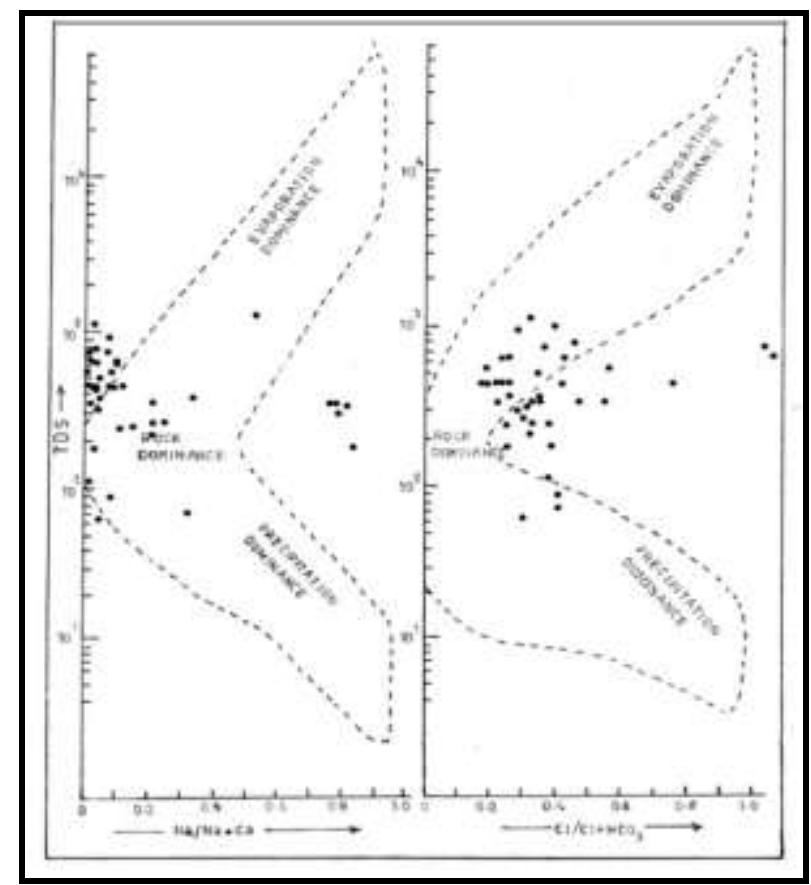

Fig. 5: Gibbs diagram of groundwater quality (premonsoon season)

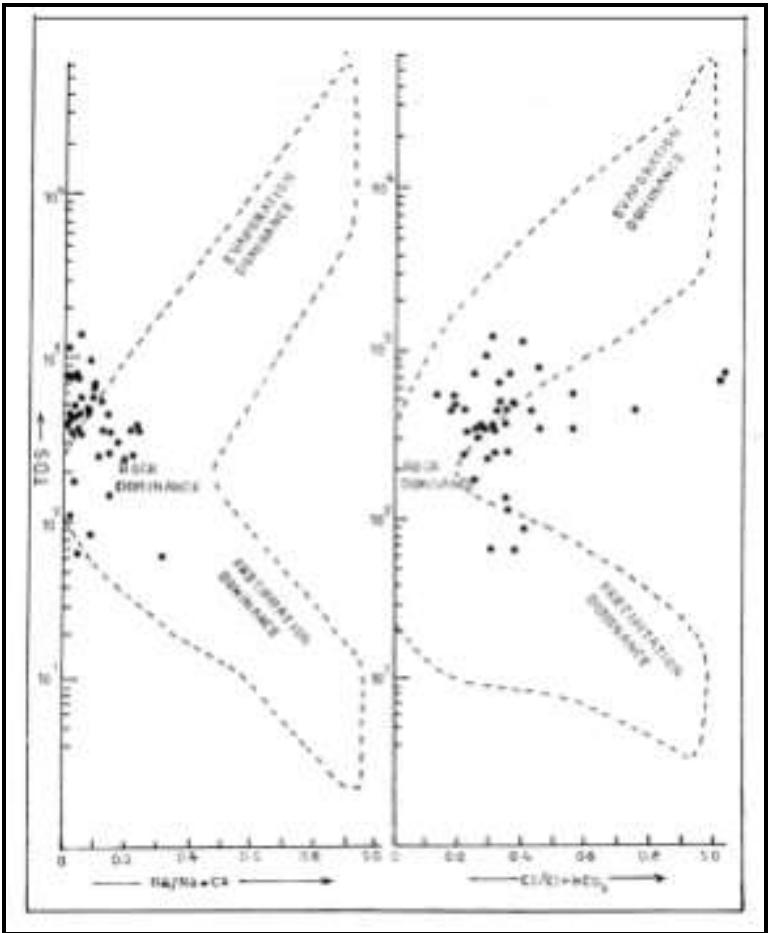

Fig. 6: Gibbs diagram of groundwater quality (postmonsoon season)

\section{CONCLUSION}

In the present investigation, interpretation of chemical analysis reveals that the groundwater is hard to very hard. The concentration of ions is maximum in pre-monsoon season as compare to post-monsoon season. The physicochemical analyses of these water samples reveal that $90 \%$ and $92.5 \%$ groundwater samples represent $\mathrm{Ca}+\mathrm{Mg}$ (alkaline earth) hydrochemical facies in pre and post-monsoon seasons respectively, whereas, $10 \%$ of groundwater samples in pre-monsoon season and $7.5 \%$ of groundwater samples in post-monsoon season represent $\mathrm{Ca}+\mathrm{Mg}>\mathrm{Na}+\mathrm{K}$ (alkaline earths exceed alkalies) hydrochemical facies. Similarly, $82.5 \%$ groundwater samples of pre-monsoon season and $77.5 \%$ groundwater samples of post-monsoon season represent $\mathrm{Cl}+\mathrm{SO}_{4}>\mathrm{HCO}_{3}+\mathrm{CO}_{3}$ (strong acid exceeds weak acid) hydrochemical facies, while $17.5 \%$ groundwater samples of pre-monsoon season and $22.5 \%$ groundwater samples of post-monsoon season belong to $\mathrm{HCO}_{3}+\mathrm{CO}_{3}>$ $\mathrm{Cl}+\mathrm{SO}_{4}$ (weak acid exceeds strong acid) hydrochemical facies. On the basis of Gibbs diagram the chemistry of groundwater belongs to precipitation dominance in premonsoon season and rock dominance in post-monsoon season.

\section{ACKNOWLEDGEMENT}

The authors are very much thankful to Management and Principal of Annasaheb Dange College of Engineering \& Technology, Ashta and Dr. J. J. Magdum College of Engineering, Jaysingpur for their continuous support and encouragement. 
Table 1: Chemical Parameters of bore well water samples from the study area (in pre-monsoon season)

\begin{tabular}{|c|c|c|c|c|c|c|c|c|c|c|c|c|c|}
\hline $\begin{array}{l}\text { Ppm } \\
\text { pre }\end{array}$ & PH & EC & TDS & TH & $\mathrm{Ca}$ & Mg & Cl & $\mathrm{HCO}_{3}$ & $\mathrm{CO}_{3}$ & TA & $\mathrm{Na}$ & $\mathbf{K}$ & $\mathrm{SO}_{4}$ \\
\hline BW1 & 8.3 & 491.4 & 527.8 & 299.2 & 108.8 & 190.4 & 39.8 & 76.2 & 44.0 & 120.0 & 6.2 & 0.9 & 45.3 \\
\hline BW2 & 6.0 & 116.7 & 505.7 & 340.0 & 95.2 & 244.8 & 34.1 & 68 & 0.0 & 68.0 & 5.1 & 1.1 & 43.5 \\
\hline BW3 & 7.0 & 150.6 & 361.9 & 204.0 & 122.4 & 81.6 & 32.7 & 44.5 & 0.0 & 44.0 & 12.7 & 6.9 & 46.2 \\
\hline BW4 & 6.2 & 182.6 & 449.6 & 313.0 & 217.6 & 95.4 & 36.9 & 56 & 0.0 & 56.0 & 4.9 & 0.3 & 24.4 \\
\hline BW5 & 9.7 & 423.6 & 440 & 218.0 & 81.6 & 136.4 & 35.5 & 60.4 & 60.0 & 120.0 & 29.0 & 6.5 & 13.0 \\
\hline BW6 & 8.2 & 730.5 & 508.4 & 245.0 & 149.6 & 95.4 & 54.0 & 132.7 & 0.0 & 132.0 & 28.2 & 23.7 & 8.7 \\
\hline BW7 & 7.1 & 822.7 & 1139.4 & 789.0 & 435.2 & 353.8 & 38.3 & 144.8 & 0.0 & 144.0 & 50.4 & 23.6 & 78.3 \\
\hline BW8 & 7.0 & 1479.8 & 1847 & 1392.0 & 693.6 & 698.4 & 85.2 & 216.3 & 0.0 & 216.0 & 63.5 & 6.6 & 68.5 \\
\hline BW9 & 7.4 & 726.7 & $\begin{array}{l}943.8 \\
\end{array}$ & 666.0 & 435.2 & 230.8 & 39.8 & 156.9 & 0.0 & 156.0 & 22.6 & 3.5 & 39.7 \\
\hline BW10 & 7.8 & 715.4 & 968.6 & 680.0 & 503.2 & 176.8 & 41.2 & 124.2 & 0.0 & 124.0 & 54.0 & 6.2 & 47.3 \\
\hline BW11 & 9.6 & 683.4 & 459.4 & 245.0 & 149.6 & 95.4 & 72.4 & 32.2 & 28.0 & 60.0 & 17.5 & 8.6 & 38.2 \\
\hline BW12 & 7.1 & 700.4 & 926.7 & 680.0 & 489.6 & 190.4 & 38.3 & 140 & 0.0 & 140.0 & 10.3 & 1.2 & 41.9 \\
\hline BW13 & 7.0 & 1235.0 & 1372.9 & 1074.0 & 530.4 & 543.6 & 71.0 & 196 & 0.0 & 196.0 & 6.2 & 0.4 & 10.4 \\
\hline BW14 & 8.1 & 293.7 & 763.6 & 612.0 & 95.2 & 516.8 & 27.0 & 60.6 & 0.0 & 60.0 & 4.0 & 1.1 & 42.9 \\
\hline BW15 & 7.7 & 606.2 & 742.6 & 530.0 & 272.0 & 258.0 & 42.6 & $\begin{array}{l}104.8 \\
\end{array}$ & 0.0 & 104.0 & 17.7 & 1.8 & 30.1 \\
\hline BW16 & 7.9 & 1016.6 & 820.4 & 490.0 & 312.8 & 177.2 & 36.9 & $\begin{array}{l}194.9 \\
\end{array}$ & 0.0 & 194.0 & 54.2 & 6.9 & 21.7 \\
\hline BW17 & 7.2 & 1188.0 & 1259.3 & 952.0 & 680.0 & 272.0 & 73.8 & 76.3 & 24.0 & 24.0 & 24.3 & 14.7 & 79.1 \\
\hline BW18 & 9.1 & 1073.1 & 564.17 & 272.0 & 163.2 & 108.8 & 72.4 & 56.87 & 32.0 & 32.0 & 19.9 & 3.7 & 90.3 \\
\hline BW19 & 7.1 & 1747.1 & 1916.2 & 1360.0 & 748.0 & 612.0 & 167.6 & 252.6 & 0.0 & 252.0 & 29.1 & 4.6 & 87.3 \\
\hline BW20 & 7.6 & 538.4 & 725.9 & 517.0 & 272.0 & 245.0 & 39.8 & 116.5 & 0.0 & 116.0 & 7.9 & 2.3 & 26.9 \\
\hline BW21 & 7.8 & 670.2 & 493 & 326.0 & 176.8 & 149.2 & 54.0 & 72.8 & 0.0 & 72.0 & 8.2 & 4.9 & 11.4 \\
\hline BW22 & 6.7 & 700.4 & 864.8 & 666.0 & 421.6 & 244.4 & 45.4 & 88.2 & 0.0 & 88.0 & 6.4 & 0.4 & 43.8 \\
\hline BW23 & 9.3 & 519.6 & 522.6 & 245.0 & 163.2 & 81.8 & 62.5 & 52.5 & 0.0 & 52.0 & 45.9 & 12 & 87.5 \\
\hline BW24 & 6.5 & 433.0 & 827.5 & 490.0 & 258.4 & 231.6 & 38.3 & 88.7 & 0.0 & 88.0 & 89.5 & 65 & 41.6 \\
\hline BW25 & 6.7 & 1142.8 & 1291.8 & $\begin{array}{l}938.0 \\
\end{array}$ & 598.4 & 339.6 & 98.0 & 176.3 & 0.0 & 176.0 & 7.9 & 0.3 & 56.7 \\
\hline BW26 & 8.1 & 357.7 & 556.3 & 272.0 & 149.6 & 122.4 & 44.0 & 92 & 0.0 & 92.0 & 40.5 & 8.4 & 83.4 \\
\hline BW27 & 7.5 & 120.5 & 438.9 & 190.0 & 136.0 & 54.0 & 32.7 & 48.1 & 0.0 & 48.0 & 64.8 & 7.3 & 80.6 \\
\hline BW28 & 6.9 & 395.4 & 889.2 & 612.0 & 408.0 & 204.0 & 34.1 & 100.5 & 0.0 & 100.0 & 54.6 & 27.4 & 45.8 \\
\hline BW29 & 6.5 & 1261.4 & 1003.8 & 680.0 & 503.2 & 176.8 & 113.6 & 144.8 & 0.0 & 144.0 & 13.4 & 3.9 & 33.7 \\
\hline BW30 & 6.7 & 790.7 & 737.4 & 490.0 & 326.4 & 163.6 & 65.3 & 128.9 & 0.0 & 128.0 & 16.1 & 1.3 & 21.2 \\
\hline BW31 & 8.1 & 389.7 & 437.6 & 245.0 & 81.6 & 163.4 & 46.9 & 76 & 0.0 & 76.0 & 15.2 & 1.2 & 37.3 \\
\hline BW32 & 8.1 & 849.1 & 492.5 & 258.0 & 122.4 & 135.6 & 99.4 & 84.2 & 0.0 & 84.0 & 8.4 & 1.6 & 24.9 \\
\hline BW33 & 6.8 & 1027.9 & 1206.4 & 898.0 & 503.2 & 394.8 & 76.7 & 152.6 & 0.0 & 152.0 & 6.5 & 0.6 & 57.3 \\
\hline BW34 & 7.9 & 568.6 & 520.8 & 259.0 & 149.6 & 109.4 & 42.6 & 96.4 & 0.0 & 96.0 & 33.6 & 10.5 & 62.9 \\
\hline BW35 & 7.0 & 611.9 & 655.5 & 449.0 & 285.6 & 163.4 & 55.4 & 104.7 & 0.0 & 104.0 & 8.7 & 2.9 & 19.9 \\
\hline BW36 & 6.5 & 504.6 & 662.6 & 435.0 & 272.0 & 163.0 & 54.0 & 64.4 & 0.0 & 64.0 & 54.1 & 12.5 & 28.2 \\
\hline BW37 & 7.3 & 482.0 & 734 & 462.0 & 258.4 & 203.6 & 41.2 & 100 & 0.0 & 100.0 & 61.6 & 23.6 & 30.4 \\
\hline BW38 & 7.0 & 602.5 & 915.6 & $\begin{array}{l}598.0 \\
\end{array}$ & 299.2 & 298.8 & 45.4 & 92.3 & 0.0 & 92.0 & 90.5 & 26.9 & 47.6 \\
\hline BW39 & 6.9 & 2046.5 & 2183.6 & 1591.0 & 924.8 & 666.2 & 125.0 & 284.8 & 0.0 & 284.8 & 60.7 & 11.6 & 95.7 \\
\hline BW40 & 7.8 & 278.6 & 464.1 & 286.0 & 190.4 & 95.6 & 39.8 & 64.7 & 0.0 & 64.0 & 35.1 & 10.2 & 12.6 \\
\hline
\end{tabular}

(All values are in $\mathrm{mg} / \mathrm{l}$ except $\mathrm{EC}$ in $\mu \mathrm{mhos} / \mathrm{cm}$ and $\mathrm{pH}$ )

Table 2: Chemical Parameters of bore well water samples from the study area (in post-monsoon season)

\begin{tabular}{|l|l|l|l|l|l|l|l|l|l|l|l|l|l|}
\hline $\begin{array}{l}\text { Ppm } \\
\text { Post }\end{array}$ & $\mathbf{P H}$ & $\mathbf{E C}$ & $\mathbf{T D S}$ & $\mathbf{T H}$ & $\mathbf{C a}$ & $\mathbf{M g}$ & $\mathbf{C l}$ & $\mathbf{H C O}_{\mathbf{3}}$ & $\mathbf{C O}_{\mathbf{3}}$ & $\mathbf{T A}$ & $\mathbf{N a}$ & $\mathbf{K}$ & $\mathbf{S O}_{\mathbf{4}}$ \\
\hline BW1 & 7.9 & 446.0 & 468.6 & 283.4 & 100.9 & 182.5 & 28.9 & 65.4 & 34.0 & 99.4 & 4.5 & 0.7 & 43.8 \\
\hline BW2 & 5.6 & 753.2 & 467.4 & 328.8 & 89.6 & 239.2 & 25.5 & 59.7 & 0.0 & 59.7 & 3.4 & 1.2 & 43.2 \\
\hline BW3 & 6.6 & 104.4 & 313.4 & 190.7 & 115.7 & 74.9 & 23.0 & 34.6 & 0.0 & 34.6 & 11.2 & 6.2 & 41.2 \\
\hline BW4 & 5.7 & 158.2 & 407.8 & 301.4 & 211.8 & 89.6 & 28.2 & 47.5 & 0.0 & 47.5 & 2.4 & 0.2 & 22.4 \\
\hline BW5 & 9.9 & 410.6 & 369.5 & 199.4 & 72.3 & 127.1 & 23.3 & 48.0 & 48.0 & 96.0 & 22.8 & 6.2 & 11.9 \\
\hline BW6 & 7.8 & 721.7 & 455 & 229.3 & 141.8 & 87.6 & 43.2 & 121.5 & 0.0 & 121.5 & 23.6 & 21.7 & 7.8 \\
\hline BW7 & 6.6 & 744.4 & 1081 & 775.5 & 428.4 & 347.0 & 28.6 & 134.5 & 0.0 & 134.5 & 42.8 & 20.6 & 72.5 \\
\hline BW8 & 6.5 & 1411.3 & 1793.8 & 1378.8 & 687.0 & 691.8 & 75.7 & 206.7 & 0.0 & 206.7 & 56.0 & 4.6 & 65.5 \\
\hline BW9 & 7.0 & 687.0 & 893.9 & 652.0 & 428.2 & 223.8 & 29.8 & 146.3 & 0.0 & 146.3 & 17.6 & 3.3 & 37.9 \\
\hline BW10 & 7.4 & 668.1 & 912.3 & 665.2 & 495.8 & 169.4 & 30.8 & 113.9 & 0.0 & 113.9 & 45.2 & 6.1 & 43.7 \\
\hline
\end{tabular}




\begin{tabular}{|c|c|c|c|c|c|c|c|c|c|c|c|c|c|}
\hline BW11 & 9.8 & 645.2 & 393.9 & 226.4 & 140.3 & 86.1 & 60.2 & 20.0 & 22.0 & 42.0 & 14.7 & 8.0 & 32.8 \\
\hline BW12 & 6.7 & 658.5 & 879.1 & 666.6 & 482.9 & 183.7 & 28.7 & 130.6 & 0.0 & 130.6 & 7.8 & 1.0 & 37.7 \\
\hline BW13 & 6.0 & 1224.6 & 1324.6 & 1060.8 & 523.8 & 537.0 & 61.4 & 186.7 & 0.0 & 186.7 & 2.3 & 0.2 & 7.2 \\
\hline BW14 & 7.7 & 250.8 & 710.6 & 596.5 & 87.4 & 509.0 & 16.3 & 49.5 & 0.0 & 49.5 & 2.3 & 1.0 & 37.4 \\
\hline BW15 & 7.8 & 576.1 & 692 & 515.2 & 264.6 & 250.6 & 32.3 & 93.9 & 0.0 & 93.9 & 14.6 & 1.5 & 26.7 \\
\hline BW16 & 7.5 & 994.9 & 758.5 & 474.9 & 305.2 & 169.6 & 26.4 & 183.7 & 0.0 & 183.7 & 35.1 & 6.3 & 24.7 \\
\hline BW17 & 6.9 & 1108.9 & 1122.9 & 938.4 & 673.2 & 265.2 & 64.1 & 9.5 & 14.0 & 4.5 & 20.3 & 14.3 & 74.4 \\
\hline BW18 & 8.7 & 982.8 & 450.2 & 254.5 & 154.4 & 100.0 & 60.7 & 11.5 & 28.0 & 16.5 & 17.9 & 3.3 & 88.7 \\
\hline BW19 & 6.8 & 1659.8 & 1861.5 & 1346.4 & 741.2 & 605.2 & 157.8 & 242.5 & 0.0 & 242.5 & 20.5 & 4.2 & 83.3 \\
\hline BW20 & 7.2 & 511.5 & 676.8 & 502.5 & 264.8 & 237.8 & 29.6 & 106.1 & 0.0 & 106.1 & 5.6 & 2.1 & 23.6 \\
\hline BW21 & 7.6 & $\begin{array}{l}658.8 \\
\end{array}$ & 446.5 & 311.1 & 169.3 & 141.7 & 43.5 & 61.8 & 0.0 & 61.8 & 6.7 & 4.2 & 11.7 \\
\hline BW22 & 6.3 & 656.6 & 816.3 & $\begin{array}{l}653.4 \\
\end{array}$ & 415.3 & 238.1 & 36.2 & 79.0 & 0.0 & 79.0 & 3.5 & 0.2 & 37.7 \\
\hline BW23 & 8.9 & 432.1 & 464 & 227.2 & 154.3 & 72.9 & 50.6 & 40.4 & 0.0 & 40.4 & 41.5 & 11 & 84.4 \\
\hline BW24 & 6.1 & 391.4 & 777 & 477.8 & 252.3 & 225.5 & 29.3 & 79.2 & 0.0 & 79.2 & 84.8 & 61 & 38.8 \\
\hline BW25 & 6.6 & 1086.1 & 1244.5 & 925.3 & 592.0 & 333.2 & 88.7 & 166.9 & 0.0 & 166.9 & 3.5 & 0.1 & 53.5 \\
\hline BW26 & 7.7 & 274.3 & 504.2 & 256.5 & 141.9 & 114.7 & 33.3 & 81.6 & 0.0 & 81.6 & 35.9 & 8.2 & 80.9 \\
\hline BW27 & 7.9 & 439.9 & 393.5 & 175.8 & 128.9 & 46.9 & 22.6 & 38.2 & 0.0 & 38.2 & 61.4 & 7.1 & 80.5 \\
\hline BW28 & 6.4 & 349.6 & 841.5 & 599.0 & 401.5 & 197.5 & 24.6 & 90.8 & 0.0 & 90.8 & 51.3 & 27.2 & 42.2 \\
\hline BW29 & 6.0 & 1227.7 & 959.9 & 667.8 & 497.1 & 170.7 & 104.5 & 135.2 & 0.0 & 135.2 & 10.1 & 3.5 & 32.8 \\
\hline BW30 & 6.3 & 769.5 & 690.1 & 477.3 & 320.1 & 157.3 & 56.0 & 119.0 & 0.0 & 119.0 & 13.4 & 1.6 & 16.4 \\
\hline BW31 & 7.6 & 352.4 & 387.2 & 229.5 & $\begin{array}{l}73.8 \\
\end{array}$ & 155.6 & 36.1 & 65.5 & 0.0 & 65.5 & 12.4 & 1.8 & 34.4 \\
\hline BW32 & 7.7 & 824.2 & 443.4 & 242.6 & 114.7 & 127.9 & 88.7 & 73.6 & 0.0 & 73.6 & 6.7 & 1.5 & 22.6 \\
\hline BW33 & 6.4 & 970.6 & 1159.8 & 885.1 & 496.8 & 388.4 & 67.3 & 142.9 & 0.0 & 142.9 & 3.4 & 0.9 & 53.7 \\
\hline BW34 & 7.4 & 387.0 & 464.4 & 244.0 & 142.1 & 101.9 & 32.2 & 85.8 & 0.0 & 85.8 & 23.2 & 10.9 & 60.9 \\
\hline BW35 & 6.9 & 319.3 & 610.9 & 435.8 & 279.0 & 156.8 & 45.8 & 94.7 & 0.0 & 94.7 & 6.7 & 2.3 & 18.7 \\
\hline BW36 & 6.0 & 179.6 & 613.5 & 422.8 & 265.9 & 156.9 & 44.9 & 55.2 & 0.0 & 55.2 & 50.3 & 11.5 & 22.8 \\
\hline BW37 & 6.4 & 163.6 & 679.5 & 448.1 & 251.5 & 196.7 & 31.3 & 90.4 & 0.0 & 90.4 & 56.0 & 20.6 & 26.6 \\
\hline BW38 & 6.6 & 214.3 & 867.3 & 584.7 & 292.5 & 292.1 & 35.8 & 82.6 & 0.0 & 82.6 & 84.9 & 26.0 & 46.8 \\
\hline BW39 & 6.7 & 1065.7 & 2131.7 & 1577.9 & 918.2 & 659.6 & 115.4 & 274.7 & 0.0 & 274.7 & 52.6 & 11.2 & 93.3 \\
\hline BW40 & 7.4 & 454.2 & 414 & 271.1 & 183.0 & 88.2 & 29.4 & 53.9 & 0.0 & 53.9 & 32.4 & 10.9 & 8,8 \\
\hline
\end{tabular}

( All values are in $\mathrm{mg} / \mathrm{l}$ except EC in $\mu \mathrm{mhos} / \mathrm{cm}$ and $\mathrm{pH}$ )

Table 3: Comparison of chemical quality standards with groundwater samples.

\begin{tabular}{|c|c|c|c|c|c|c|c|}
\hline \multirow[b]{2}{*}{$\begin{array}{l}\text { Sr. } \\
\text { No. }\end{array}$} & \multirow{2}{*}{$\begin{array}{l}\text { Water } \\
\text { Quality } \\
\text { Parameters }\end{array}$} & \multicolumn{2}{|c|}{$\begin{array}{l}\text { WHO International } \\
\text { Standards (2004) }\end{array}$} & \multicolumn{2}{|c|}{$\begin{array}{l}\text { Indian Standards } \\
\text { (ISI 10500, 1993) }\end{array}$} & \multicolumn{2}{|c|}{ Range in the study Area } \\
\hline & & $\begin{array}{l}\text { Most } \\
\text { Desirable } \\
\text { Limit }\end{array}$ & $\begin{array}{l}\text { Max. } \\
\text { Allowable } \\
\text { Limit }\end{array}$ & $\begin{array}{l}\text { Highest } \\
\text { Desirable }\end{array}$ & $\begin{array}{l}\text { Max. } \\
\text { Permissible }\end{array}$ & $\begin{array}{l}\text { Pre-monsoon } \\
\text { Season }\end{array}$ & $\begin{array}{l}\text { Post-monsoon } \\
\text { Season }\end{array}$ \\
\hline 1 & $\mathrm{pH}$ & 6.5 & 8.5 & $6.5-8.5$ & $6.5-9.5$ & $6.0-9.7$ & $5.6-9.9$ \\
\hline 2 & EC & 1400 & - & - & - & $116.7-2046.5$ & $104.4-1659.8$ \\
\hline 3 & TDS & 500 & 1,500 & 500 & 2,000 & $361.9-2183.6$ & $313.4-2131.7$ \\
\hline 4 & $\mathrm{TH}$ & 100 & 500 & 300 & 600 & $204-1591$ & $190.7-1577.9$ \\
\hline 5 & $\mathrm{Ca}^{2+}$ & 75 & 200 & 75 & 200 & $81.6-924.8$ & $72.3-918.2$ \\
\hline 6 & $\mathrm{Mg}^{2+}$ & 50 & 150 & 30 & 100 & $54-698.4$ & $46.9-691.8$ \\
\hline 7 & $\mathrm{Na}^{+}$ & - & 200 & - & 200 & $4-90.5$ & $2.3-84.9$ \\
\hline 8 & $\mathrm{~K}^{+}$ & - & 12 & - & - & $0.4-65$ & $0.2-61$ \\
\hline 9 & TA & - & - & 200 & 600 & $44-284.8$ & $23.5-274.7$ \\
\hline 10 & $\mathrm{HCO}_{3}{ }^{2-}$ & - & - & - & - & $44-284.8$ & $9.5-274.7$ \\
\hline 11 & $\mathrm{SO}_{4}^{2-}$ & 200 & 400 & 200 & 400 & $8.7-95.7$ & $7.2-93.3$ \\
\hline 12 & $\mathrm{C}^{--}$ & 200 & 600 & 250 & 1000 & $27-167.6$ & $16.3-157.8$ \\
\hline
\end{tabular}




\section{REFERENCES}

[1]. National Water Policy, As recommended by National Water Board in its 14th meeting held on 7th June, 2012.

[2]. R. Ravichandra and O.S. Chandana, "Study on evaluation on groundwater pollution in Bakkannaplem, Visakhapatnam", Nature, Environment and Pollution Technology, 5(2), 203-207., 2006.

[3]. APHA., "Standard methods for the examination of water and wastewater", American Public Health Association, Washington, 1998.

[4]. BIS, "Drinking water specification", Bureau of Indian Standards, New Delhi, IS: 10500, 11, 2003.

[5]. WHO, "Guidelines for drinking water quality", Geneva, World Health Organization, 2004.

[6]. C. N. Sawyer, P.L. Mccarty and G.F. Parkin, "Chemistry for environmental engineering and science", 5th edition, New York McGraw-Hill, 2003.

[7]. S. M. Deshpande and K. R. Aher, "Evaluation of groundwater quality and its suitability for drinking and agriculture use in parts of Vaijapur, district Aurangabad, MS, India", Research Journal of Chemical Sciences, Vol. 2(1), pp. 25-31, 2012.

[8]. M. Piper, "A graphic procedure in geochemical interpretation of water analyses", Trans American Geophysical Union, 25, pp. 914-923, 1944.

[9]. R. J. Gibbs, "Mechanisms controlling world water chemistry", Science, 17, pp. 1088-1090, 1970.

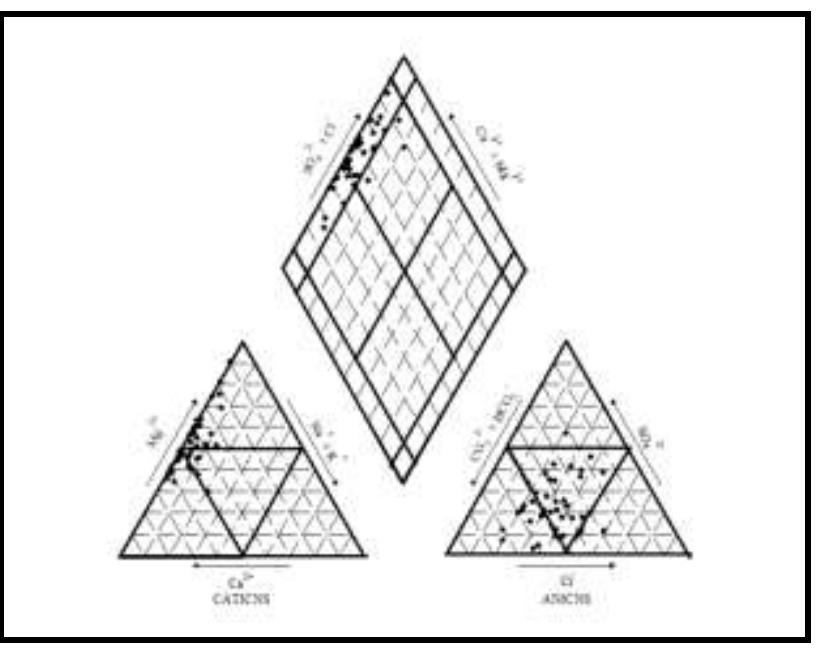

